\title{
PENINGKATAN PENGETAHUAN ERGONOMI TERHADAP PEMBUAT KONVEKSI TAS
}

\author{
${ }^{1)}$ Fandita Tonyka Maharani* \\ ${ }^{1)}$ Program Studi Kesehatan Masyarakat, Fakultas Ilmu Kesehatan \\ Universitas Pembangunan Nasional Veteran Jakarta \\ Email Korespondensi: fanditatonykamaharani@gmail.com
}

\begin{abstract}
ABSTRAK
Konveksi memiliki peran yang besar terhadap peningkatan sosial dan ekonomi masyarakat. Akan tetapi, proses kerja di industri konveksi memiliki risiko kesehatan dan keselamatan terhadap pekerja. Hasil observasi pendahuluan menunjukkan bahwa pekerja konveksi $\mathrm{X}$ bekerja lebih dari 12 jam per hari. Diketahui pula bahwa tempat kerja (work station) yang digunakan kurang ergonomis. Pengabdian masyarakat ini bertujuan untuk memberikan informasi yang relevan terkait aspek ergonomi terhadap pembuat tas. Pemberian informasi ergonomis dilakukan terhadap 6 orang pekerja konveksi PT. X. Advokasi melalui diskusi langsung dilakukan terhadap pemilik konveksi. Pre-Test dan Post-Test diberikan kepada pekerja yang menunjukkan peningkatan skor setelah dilakukan pemberian informasi. Pemilik konveksi $\mathrm{X}$ bersedia untuk mengubah work station dan penyesuaian tugas para pekerja. Diharapkan dengan peningkatan pengetahuan pada pekerja sekaligus penyesuaian work station dan tugas dapat menurunkan risiko keluhan musculoskeletal pada pekerja PT.X
\end{abstract}

Kata Kunci : ergonomi, konveksi, pembuat tas

\section{ABSTRACT}

It has been known that convection industry has the big impact to improve the social and economic aspects among society. However, the work processes in the industry have the health and safety risks. The preliminary observation shows that the workers of Convection $X$ work more than 12 hours a day. It also been observed that the work station was lack of ergonomic aspect. The ergonomic information and knowledge were given to 6 workers. The advocation was conducted to the owner. Pre-Test and Post-Test was conducted to the workers and show the score improvement after the counselling was delivered. The owner agreed to change the work station and adjust the workers' tasks.

Keywords: ergonomics, convection, bag maker 
Volume. 1 No. 2 tahun 2020

Nov 2020 - Mei 2021
ISSN (online): 2722-2055 https://jurnal.umj.ac.id/index.php/ASSYIFA
AS-SYIFA: Jurnal Pengabdian dan Pemberdayaan Kesehatan Masyarakat

\section{PENDAHULUAN}

Telah diketahui bahwa industri kecil dan menengah memiliki peran dan dampak yang besar terhadap masyarakat, khususnya dalam bidang sosial dan ekonomi. Studi terdahulu menyatakan bahwa industri kecil dan menengah dapat menyerap tenaga kerja sekaligus meningkatkan pendapatan eknomi pada masyarakat (Shofi, 2019). Konveksi merupakan salah satu contoh industri kecil yang mempunyai peranan penting tersebut. Amsah (2016) menyatakan bahwa usaha konveksi dapat meningkatkan upah dan kesejahteraan bagi masyarakat.

Setiap industri memiliki bahaya dan risiko terhadap kesehatan, tidak terkecuali terhadap industri konveksi. Penelitian terdahulu menyatakan bahwa pekerjaan yang monoton, repetitif (berulang), dan dilakukan dalam jangka waktu yang lama dapat berisiko terhadap terjadinya gangguan pada otot rangka (OSHA, 2000). Ergonomi adalah ilmu yang mempelajari penyelarasan pekerjaan terhadap pekerja alih-alih memaksa pekerja untuk menyesuaikan diri terhadap pekerjaannya (OSHA, 2000). Gangguan terhadap otot rangka tersebut dapat dicegah dan diminimalisir dengan cara melakukan penyesuaian tugas, tempat kerja (work station), dan peralatan (OSHA, 2000). Beberapa studi menyatakan bahwa pekerja sektor konveksi mempunyai keluhan musculoskeletal yang tinggi (Sjarifah and Rosanti, 2019); (Wulandari, 2017); (Setiawan, 2019); (Wijaya, 2019); (Nooryana, Adiatmika and Purnawati, 2020); (Sukmawati, 2020); (Candrawati, 2020).

Konveksi X yang memproduksi tas berada di kota Depok, Jawa Barat. Hasil studi pendahuluan yang melibatkan observasi dan wawancara menunjukkan bahwa para pekerja konveksi $\mathrm{X}$ bekerja lebih dari 12 jam dengan menggunakan tempat kerja (work station) yang tidak ergonomis. Pekerja menggunakan kursi tanpa sandaran punggung, tangan, dan bantalan duduk. Selain itu, diketahui pula bahwa pekerjaan pembuatan tas tersebut dilakukan dengan sistem on demand yang mengharuskan pekerja untuk bekerja lembur tanpa istirahat sesuai dengan tenggat waktu permintaan klien.

Pengabdian masyarakat dilakukan langsung pada konveksi $\mathrm{X}$ dengan metode pemberian informasi ergonomi terhadap pekerja dan advokasi terhadap pemilik konveksi $\mathrm{X}$. Diharapkan pemilik konveksi $\mathrm{X}$ dapat memperbaiki work station dan pembagian tugas yang ada. Pemberian informasi kepada pekerja diharapkan dapat meningkatkan pengetahuan dan kesadaran pekerja untuk bekerja dengan sehat dan selamat.

\section{METODE}

Pengabdian masyarakat dilakukan secara langsung pada konveksi X yang berlokasi di kota Depok, Jawa Barat pada 22 Oktober 2019. Pemberian informasi menggunakan metode ceramah dan diskusi tanya jawab secara langsung dilakukan terhadap 6 orang pekerja konveksi X. Advokasi dilakukan dengan cara diskusi langsung kepada pemilik konveksi X. Standing banner dan booklet digunakan sebagai media pemberian informasi mengenai ergonomi. Pre-test dan post-test dilakukan untuk mengetahui peningkatan pengetahuan ergonomi pekerja.

\section{HASIL DAN PEMBAHASAN}

Pemberian informasi ergonomi terhadap pekerja dilakukan dengan metode ceramah dan diskusi langsung. Informasi ergonomi yang diberikan meliputi posisi kerja yang benar (posisi kaki, tangan, dan anggota tubuh lainnya) (Gambar 1). Advokasi dilakukan dengan cara diskusi langsung kepada pemiliki konveksi. Bapak A sebagai pemilik konveksi telah 
AS-SYIFA: Jurnal Pengabdian dan Pemberdayaan Kesehatan Masyarakat

menyetujui untuk mengganti kursi kerja menjadi lebih ergonomis dengan menambahkan bantalan duduk, sandaran punggung, dan sandaran tangan.

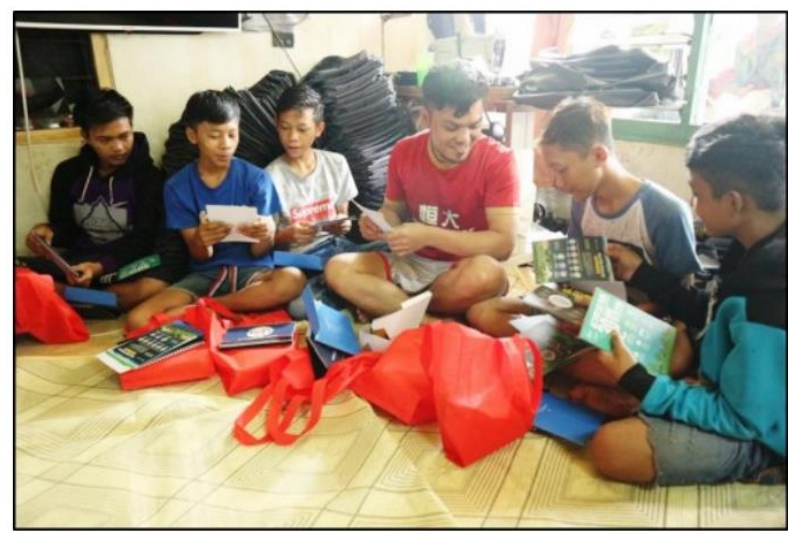

Gambar 1. Pekerja berdiskusi saat Pemberian Informasi Ergonomi

Pre-test dan post-test yang terdiri dari 10 pertanyaan tentang ergonomic diberikan terhadap 6 pekerja untuk mengetahui apakah terdapat peningkatan pengetahuan ergonomi. Tabel 1 menunjukkan bahwa semua pekerja (6 orang) tidak pernah mendengar sama sekali tentang ergonomi. Setelah dilakukan pemberian informasi ergonomi, 4 orang pekerja mendapatkan skor 80 , sementara 1 pekerja mendapatkan skor 90, dan 1 pekerja lainnya mendapatkan skor 100.

Tabel 1. Perbandingan Hasil Pre-Test dan Post-Test

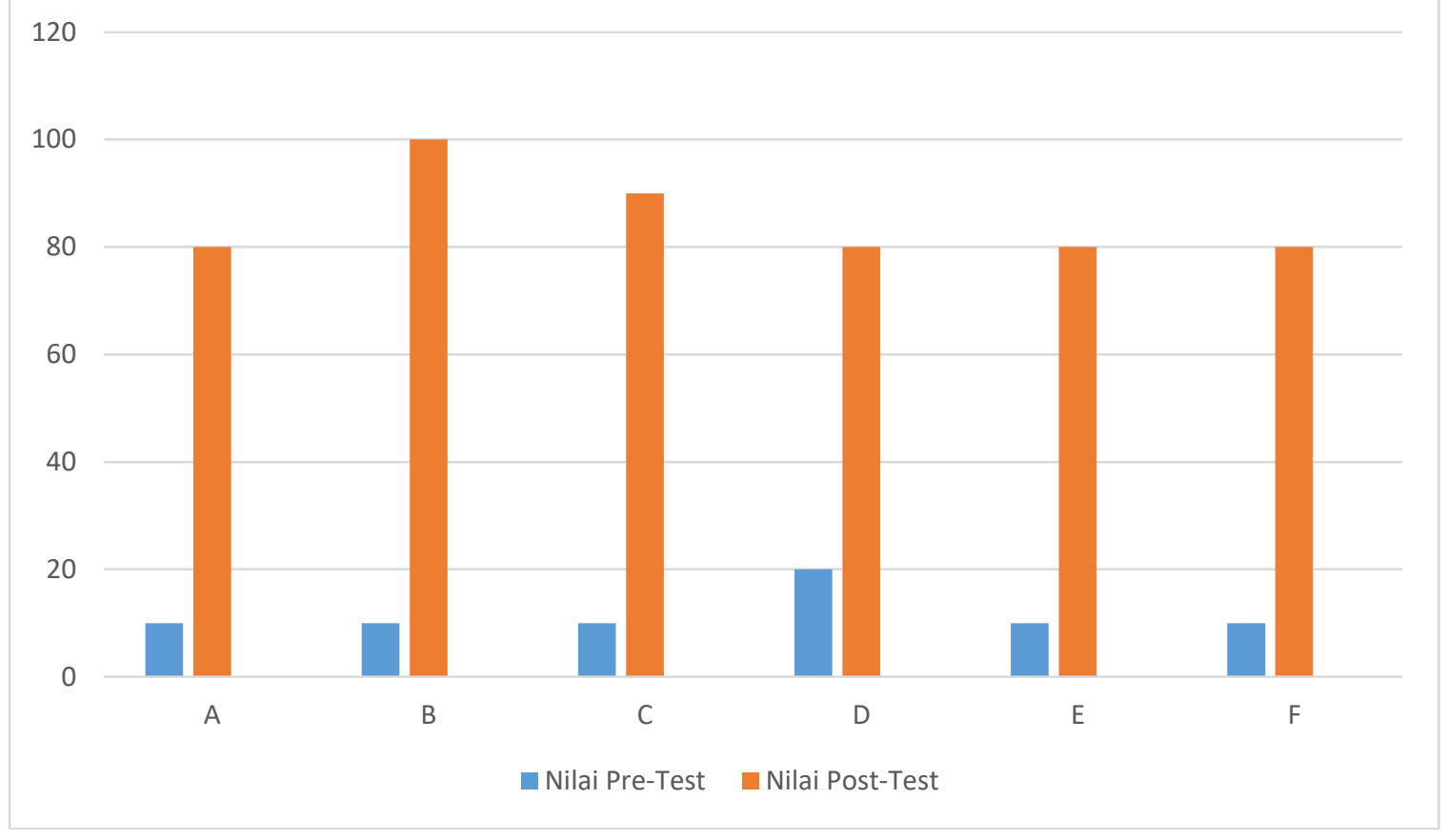

Pemberian informasi ergonomi dan advokasi merupakan salah satu cara untuk meningkatan kesehatan dan keselamatan pekerja. OSHA (2000) menyatakan bahwa pencegahan gangguan otot dan rangka dilakukan dengan cara penyesuaian tugas, tempat kerja (work station), dan 
Volume. 1 No. 2 tahun 2020 Nov 2020 - Mei 2021
ISSN (online): 2722-2055 https://jurnal.umj.ac.id/index.php/AS-

SYIFA

AS-SYIFA: Jurnal Pengabdian dan Pemberdayaan Kesehatan Masyarakat

peralatan. Melalui kegiatan pengabdian masyarakat ini pemilik konveksi bersedia untuk meyediakan work station yang lebih ergonomis. Advokasi kepada pemilik konveksi juga menghasilkan rekomendasi berupa penyesuaian tugas dan tenggat waktu sehingga pekerja tidak merasa kelelahan. Hasil pre-test dan post-test 6 orang pekerja menunjukkan bahwa mereka mendapatkan pengetahuan yang lebih baik lagi mengenai ergonomi.

\section{KESIMPULAN DAN SARAN}

Pengabdian masyarakat terhadap konveksi X menghasilkan kesediaan pemilik konveksi untuk mengubah work station menjadi lebih ergonomis. Selain itu, pemilik konveksi juga bersedia untuk menyesuaikan tugas dan tenggat waktu pekerjaan sehingga pekerja tidak merasa kelelahan. Hasil pre-test dan post-test 6 orang pekerja menunjukkan bahwa mereka mendapatkan pengetahuan yang lebih baik lagi mengenai ergonomi.

\section{DAFTAR PUSTAKA}

Shofi, Siska Ariyani. (2019). Peran industri kecil dalam meningkatkan perekonomian masyarakat menurut perspektif ekonomi Islam : studi kasus pada usaha konveksi jilbab di Desa Pendosawalan Kec. Kalinyamatan Kab. Jepara. Undergraduate (S1) thesis, UIN Walisongo Semarang.

Amsah, Ridwan April. (2016). Peran Sosial Ekonomi Pengusaha Konveksi Tas Terhadap Kaum Dhuafa (STUDI KASUS KONVEKSI TAS MUSLIADI DAN KONVEKSI TAS KACUS DI RT 04 RW 09 KELURAHAN BINTARA BEKASI BARAT). Available from: http://repository.uinjkt.ac.id/dspace/handle/123456789/32355 (Accessed 4 September 2020)

OSHA. 2016. Occupational Safety and Health in the Textiles Sector. Available from: http://www.osha.mddsz.gov.si/resources/files/pdf/E-fact 30_Occupational_safety_and_health_in_the_textiles_sector.pdf (Accessed 4 November 2016)

Candrawati, H. R. (2020) 'Effectiveness Of Giving Additional Food With Stretching Exercise And Short Breaks On Work Fatique And Musculoskeletal Disorder Of Production Workers PT . Rekaindo Global', 3(2), pp. 701-710. doi: 10.30994/jqph.v3i2.122.

Nooryana, S., Adiatmika, I. P. G. and Purnawati, S. (2020) 'Latihan Peregangan Dinamis Dan Istirahat Aktif Menurunkan Keluhan Muskuloskeletal Pada Pekerja Di Industri Garmen', 06(01), pp. 61-67.

Setiawan, H. (2019) 'Muskuloskeletal Pada Pekerja Bagian Packing'.

Sjarifah, I. and Rosanti, E. (2019) 'ANALISIS TINGKAT RISIKO KELUHAN MUSCULOSKELETAL DISORDERS (MSDs) PADA PEKERJA USAHA KECIL KONVEKSI BANGSRI, KARANGPANDAN', Journal of Industrial Hygiene and Occupational ..., 3(2). Available at: https://core.ac.uk/download/pdf/235573609.pdf.

Sukmawati, I. (2020) 'HIGEIA JOURNAL OF PUBLIC HEALTH Potensi Bahaya pada Home industry Konveksi’, 4(3), pp. 384-396.

Wijaya, K. (2019) 'Identifikasi Risiko Ergonomi dengan Metode Nordic Body Map Terhadap Pekerja Konveksi Sablon Baju', Keselamatan dan Kesehatan Kerja, 1, pp. 2-3. 
Volume. 1 No. 2 tahun 2020 Nov 2020 - Mei 2021
ISSN (online): 2722-2055 https://jurnal.umj.ac.id/index.php/AS-
AS-SYIFA: Jurnal Pengabdian dan

Pemberdayaan Kesehatan Masyarakat

Available at: https://idec.ft.uns.ac.id/wp-content/uploads/2019/05/ID075.pdf.

Wulandari, D. R. (2017) 'Risiko Ergonomi dan Keluhan Musculosceletal Disorders pada Penjahit',

Undergraduate

Thesis.

Available

at:

https://repository.unej.ac.id/bitstream/handle/123456789/84829/Dinar Rizki Wulandari -122110101061_.pdf? sequence $=1$ \&isAllowed=y. 
